\title{
Analysis of Ratio and Financial Performance of Open Company Pharmaceutical Industry Which has Been Listing in Indonesia Stock Exchange (Case Study in Pharmaceutical Company PT. Kimia Farma.Tbk)
}

\author{
Tri Wartono ${ }^{1}$, Muliahadi Tumanggor ${ }^{2}$, Bulan Oktrima ${ }^{3}$, Veta Lidya Delimah \\ Pasaribu $^{4}$ \\ University of Pamulang \\ Dosen00126@unpam.ac.id'1, Dosen00871@unpam.ac.id², Dosen00790@unpam.ac.id³, \\ dosen01889@unpam.ac.id ${ }^{4}$
}

\begin{abstract}
The financial performance of a company is one indication, whether the company has been running and developing in accordance with the demands and rules of good management. Every company was founded with the hope of staying there forever without thinking about bankruptcy (Going concern), so that in order to survive the company must increase the value of assets by fostering sustainable profits. Good financial performance can be seen from the financial ratios as well as periodic company evaluations. This study aims to analyze the financial performance of pharmaceutical companies in Indonesia in order to determine how far the company's performance and sustainability is developing and where the company's position is compared to other similar companies (Industry Average Standards). One of them is PT. Kimia Farma, Tbk for the past three years. Also to find out the comparison between ratios and financial performance of PT. Kimia Farma, Tbk with ratios from 2016 to 2018. Ratios analyzed cover core financial ratios namely liquidity ratios, solvency ratios, activity ratios and profitability ratios. Industry average ratios were also compiled with the same reference during the periods of 2016, 2017 and 2018. Analysis of the first financial ratios and performance with the horizontal method of comparing the movements of ratios that have been calculated with the previous year. While the second with a vertical method that compares the ratio of PT. Kimia Farma, Tbk with similar company ratios (industry average. Industry Average Ratios are prepared based on the ratios of four similar companies, namely PT Kimia Farma, PT. Kalbe Farma, PT. DaryaVaria, and PT. Indofarma. The concept of financial performance analysis by evaluating past performance and then predicting future performance Analysis Stages include: (1) Time series analysis, which is calculating financial ratios and comparing from year to year for the company (2) Common Size Analysis, namely the presentation of the balance sheet reporting percentage (Common Size Balance Sheat), income statement or loss presentation (Common Size Income Steatment) and cash flow statement (Common Siza Cash Flow). (3) Cross Sectional Analysis that is by comparing the company's financial ratios with the average ratio industry (Similar Companies) (4) Calculation and preparation of the average ratio of the pharmaceutical industry. The results of the analysis will be able to know the trend of improving the performance of the company under study both in terms of the development of financial ratios and the development of asset values and balance sheet and profit-loss structure and cash flow proportions and the company's position compared to other similar companies. Time Series Analysis will show the results of the calculation of the ratio a few years ago with a graph besides being able to compare time flats, it can also be seen in future trends. Common size analysis will show asset quality, structural capital and income proportion, so that it can be seen an increase and decrease in company performance. Cross Sectional Analysis will find out whether the company's position is above average, below average or equal to industry average. And with the compilation of
\end{abstract}




\begin{abstract}
an average ratio of the pharmaceutical industry, it can be used as a reference and standard for financial performance in assessing the performance of all pharmaceutical companies in Indonesia. Horizontal analysis shows that out of 16 ratios are under healthy criteria such as low liquidity, very low activity ratios. Liquidity difficulties, low accounts receivable turnover and inventory turnover have caused the company's management and operations to be suboptimal and there has been a downward trend of all indicators from 2016 to 2018. In line with the decline in performance of PT. Kimia Farma, when compared to the industry average ratio, turns out that all ratios are below the industry average ratio. Only one indicator is ROE which is greater than the industry average ratio. This is confirmed that the assets of PT. Kimia Farma, Tbk is far less productive than the assets of similar companies with low asset turnover.
\end{abstract}

Keywords: Financial Ratios, Financial Performance, Industry Average Ratio Time Series Analysis, Cross Sectional Analysis, Common Size Analysis and Pharmacy Industry Average Ratios

\title{
1 Introduction
}

In the face of the era of corruption which is marked by changes today, it requires companies to be able to further improve their performance in order to survive in the face of economic developments that are always changing quickly and dynamically. Performance is an important thing that must be achieved by every company, because performance is a picture of the achievement or achievement of a company. In investing activities, the most valued is the company's financial performance as measured by financial statements.

In Indonesia there are many industries that have gone public and are listed on the Indonesia Stock Exchange (IDX), one of which is a manufacturing company engaged in the pharmaceutical industry. The pharmaceutical world in Indonesia has not experienced much change, but little by little the pharmaceutical world in Indonesia has begun to improve. One of their better company operations is to make their company go public or to make a public offering to the public. This is done for the good of the company and Indonesia's health through the pharmaceutical world, with the advancement of the pharmaceutical world, Indonesia's health will improve and Indonesia can become a more developed country both in the world of health and its economy. There are many pharmaceutical companies in Indonesia, but there are only ten companies listed on the IDX or already publicly listed. The growth of pharmaceutical companies in Indonesia slowed mainly due to rising inflation, the exchange rate plummeted and foreign investment fell lower. In addition to a weakening currency, rising electricity prices and rising minimum wages have also put pressure on pharmaceutical companies, both dosbacks and foreigners.

PT. Kimia Farma, Tbk (KAEF) is a company engaged in the first pharmaceutical industry in Indonesia which was founded by the Dutch East Indies Government in 1817, the company's performance is currently experiencing fluctuations in its financial ratios. PT. Kimia Farma Tbk is also trying to improve the quality of financial performance in the company, so that the company's financial performance is up to standard and remains stable. Based on the description above, this study is intended to determine the performance of pharmaceutical companies in the 2016-2018 period in terms of financial ratios, especially PT. Kimia Farma, Tbk and at the same time compare with the performance of similar companies. Thus, it can be taken the title "Analysis of Financial Ratios of Pharmaceutical Industry Open Companies (Study at PT. Kimia Farma, Tbk. Period 2016-2018"). 
Based on the above background, problem identification and problem limitation, the authors formulate the problemas follows:

a) How is the financial performance of PT. Kimia Farma, Tbk period 2016-2018 seen from the results of the measurement of financial ratios?

b) How can the average standard ratio of the pharmaceutical industry be arranged for the period 2016- 2018?

c) How is the financial performance of PT. Kimia Farma, Tbk period 2016 - 2018 when compared with the average industry ratio?

\section{Literature Review}

\subsection{Financial Ratio Analysis}

Analysis of the company's financial ratios is very important for a potential investor to determine how much investment he can provide. From the results of the analysis can also be used as a reference for business development. So that those who need are not only investors but also company management. According to Kasmir (2012: 104), it is concluded that the analysis of financial ratios illustrates a relationship and a comparison between the amount of one account with another amount in the financial statements. By using analytical methods such as this ratio will be able to explain or provide a picture of the good or bad state of the company's financial position. The purpose of analyzing the company's financial statements in empowering all available resources to achieve the targets set by the company.

\subsection{Types of Financial Ratios}

According to V.Wiratna Sujarweni (2017: 60) namely the types of financial ratios based on the source, the financial ratios can be classified into 3 groups as follows: (1) Balance Ratios, i.e. ratios originating from accounts balance sheet; (2) Ratios of income statement, namely ratios originating from income statements and (3) Ratios between reports, i.e. ratios originating from both income statements / income statements.

\section{Research Methods}

\subsection{Research Scope}

The research object chosen by the author is a pharmaceutical industry company listed on the Indonesia Stock Exchange, namely PT. Kimia Farma Tbk, by taking the period of calculation of financial statements from 2016-2018. To obtain data and information in writing this thesis, the author has conducted research through the Indonesia Stock Exchange website (www.idx.co.id).

\subsection{Data Collection Methods}

This study uses secondary data that is data obtained from the company as research objects that have been processed and documented in the company, for example a brief history of the 
company (Sugiyono (2001: 21). The data is in the form of company documents that are examined using various sources of literature. is an annual report and a company's financial report. In this study, secondary data obtained from PT Kimia Farma Tbk's financial statements from 2016 to 2018 .. For the purposes of comparison and compilation of industry average ratios, secondary data in the form of financial statements from companies PT Kalbe Farma, PT Indo Farma and PT Darya Varia all pharmaceutical companies listed on the IDX

\subsection{Data Analysis Methods}

Analysis of the data used is descriptive quantitative which is a ratio analysis based on calculations to find out the level of the ratio and find a picture of the financial performance of the company PT.Kimia Farma Tbk, the most commonly used method for conducting the first comparison is Time series analysis, which compares between times or between periods, with the goal that later trends / trends will be seen.

\section{a) Horizontal analysis (Time series analysis)}

Analysis of the ratio calculation is continued by comparing the ratio with the ratio of the following years. The 2016 ratio compared to the 2017 ratio, and the 2017 ratio with the 2018 ratio, so that the movements / trends / trends of each type of ratio can be seen. Ratio calculation will include the following analysis:

a) Liquidity Ratio: (1) Current ratio (2) Quick Ratio (3) Cash ratio

b) Solvency Ratio: (1) Debt to Asset Ratio (DAR) (2) Debt to Equity Ratio (3) Long Term Debt to Equity Ratio (LTDtER)

c) Profitability Ratios: (1) Gross profit margin (2) Net profit margin (3) Return an Asset (ROA) (4) Return on Equit (ROE),

d) Activity Ratios: (1) Receivable Turnover, (2) Inventory Turn Over, (3) Working Capital Turnover, (4) Fixed Assets Turnover, (5) ) Total Assets Turnover

\section{b) Analysis of Industry Average Ratio}

To get an industry average ratio, it needs to be arranged with the following stages:

a) Determine which companies will be used as the basis of calculation, namely selected pharmaceutical companies, namely: PT. Kimia Farma, PT. IndoFarma, PT. Kalbe Farma and PT daria Varia

b) Calculate each item ratio of all selected companies for the 2016 to 2018 period, and add up the ratio items for each of the four companies

c) From the sum of each type of ratio divided by four (four companies) the result is the industry average ratio for that type of ratio

d) The calculation results can be summarized in a table of Industry Average Ratios

\section{c) Vertical Analysis (Cross section analysis)}

With the Vertical analysis model (Cross sectional approach), which is to make comparisons of the results of the calculation of ratios that have been made between one company and other companies in the same scope carried out simultaneously. From the results of using these two methods, it is expected that a conclusion can be made stating that the company's position is in a condition below average, average or above average which also shows the company's performance compared to the average performance of similar 
companies, namely with the following steps:

a) Interpreting various problems found. At this stage the analysis looks at the company's financial performance after the three stages are then interpreted to see what are the problems and constraints experienced by the banking sector.

b) Finding and providing solutions to problems found. In this last stage, after various problems have been encountered, a solution is sought to provide an input or input so that what becomes obstacles and obstacles can be resolved so far.

\section{Research Discussion And Results}

\subsection{Financial Ratio Analysis Time Series / Horizotal Analysis of PT. Kimia Farma, Tbk}

The analysis is done by calculating financial ratios and from the calculation results are interpreted for each subsequent year comparing the results of the next year and the next by looking at the trends or trends of each ratio.

\subsection{Liquidity Ratio Analysis}

Liquidity ratio is the company's ability to pay short-term debts (maximum one year) with the amount of current assets owned.

Table 1. Results of Current Ratio Calculation for the period of 2016-2018

\begin{tabular}{lrrrrr}
\hline Years & Current Asset & Current lialibilities & Current Ratio Delta (+/-) & Information \\
\hline 2016 & $2,906,737$ & $2,341,155$ & $1.24 \%$ & - & Enought \\
2017 & $3,662,090$ & $3,523,628$ & $1.04 \%$ & $-0,20$ & Go down \\
2018 & $5,369,547$ & $6,103,968$ & $0.88 \%$ & $-0,16$ & Go down \\
\hline
\end{tabular}

PT. Kimia Farma Tbk has Current Ratio from 2016 to 2018 respectively of 1.24\%, 1.04\% and $0.88 \%$. This figure shows a slow decline from 2016 to 2018 . This shows that the growth of current assets is greater than the growth of its current debt, so it is getting lower so it is not healthy.

Table 2. Quick Ratio Calculation Results for the period of 2016-2018

\begin{tabular}{ccccccc}
\hline Years & $\begin{array}{c}\text { Current } \\
\text { Asset }\end{array}$ & Stock & $\begin{array}{c}\text { Current } \\
\text { lialibilities }\end{array}$ & QR & delta (+/-) & Information \\
\hline 2016 & 2.906 .737 & 967.330 & 2.341 .155 & $0.83 \%$ & - & Not Good \\
2017 & 3.662 .090 & 1.192 .342 & 3.523 .628 & $0.70 \%$ & $-0,13$ & Go down \\
2018 & 5.369 .547 & 1.805 .736 & 6.103 .968 & $0.58 \%$ & $-0,12$ & Go Down \\
\hline
\end{tabular}

The quick ratio based on the table is $0.83 \%$ in $2016,0.70 \%$ in 2017 , and $0.58 \%$ in 2018 . It can be seen that the results of the QR calculation starting from 2016 experienced $0.83 \%$ in 2017 to $0,70 \%$ and again decreased in 2018 by $0.58 \%$.Quick ratio is a ratio used to measure the ability of companies to pay short-term liabilities by using more liquid assets that are getting worse. 
Table 3. Cash Ratio Calculation Results for the period of 2016-2018

\begin{tabular}{cccccc}
\hline Years & Cash & $\begin{array}{c}\text { Current } \\
\text { lialibilities }\end{array}$ & $\begin{array}{c}\text { Cash } \\
\text { Ratio }\end{array}$ & $\begin{array}{c}\text { Delta } \\
(+/-)\end{array}$ & Information \\
\hline 2016 & 647.684 & 2.341 .155 & $0.28 \%$ & - & not healthy \\
2017 & 989.637 & 3.523 .628 & $0.28 \%$ & 0 & Constant \\
2018 & 1.960 .038 & 6.103 .968 & $0.32 \%$ & $+0,04$ & Go up \\
\hline
\end{tabular}

Source: Processed data

Table-based cash ratios are $0.28 \%$ in $2016,0.28 \%$ in 2017 and $0.32 \%$ in 2018 . The results of this ratio in 2016 and 2017 have the same value, but in 2018 an increase of $0.32 \%$. Cash ratio illustrates how much cash and cash equivalents a company has to pay its short-term debt. Increased even though each is less healthy.

\subsection{Solvency Ratio Analysis}

Namely a ratio that measures the extent to which companies are financed by debt. Solvency ratios measure the ratio between funds provided by a company owner and funds that come from company credit.

Table 4. Debt to Asset Ratio Calculation Results for the period of 2016-2018

\begin{tabular}{cccccc}
\hline Years & $\begin{array}{c}\text { the amount } \\
\text { of debt }\end{array}$ & $\begin{array}{c}\text { the amount of } \\
\text { Asset }\end{array}$ & DAR & $\begin{array}{c}\text { Delta } \\
(+/-)\end{array}$ & Information \\
\hline 2016 & 1.696 .209 & 5.369 .547 & $31,58 \%$ & - & Healthy \\
2017 & 2.369 .507 & 4.090 .881 & $57,92 \%$ & $+26,33$ & Go up \\
2018 & 3.774 .304 & 9.460 .427 & $39,90 \%$ & $-18,02$ & Go dwon \\
\hline
\end{tabular}

PT Kimia Farma has a DAR value in 2016 of $70.29 \%$, in $201757.92 \%$, and in 2018 of $39.90 \%$. From year to year there is a decrease, meaning that the burden of pharma chemical debt decreases compared to the total assets owned. The movement is an indication of the improving financial situation of PT. Kimia Farma.

Table 5. Debt to Equity Ratio Calculation Results for the period of 2016-2018

\begin{tabular}{cccccc}
\hline Years & $\begin{array}{c}\text { the amount } \\
\text { of debt }\end{array}$ & $\begin{array}{c}\text { the amount of } \\
\text { Ekuitas }\end{array}$ & DER & delta (+/-) & Information \\
\hline 2016 & 1.696 .209 & 2.271 .407 & $74,68 \%$ & - & Good \\
2017 & 2.369 .507 & 2.572 .521 & $92,11 \%$ & $+17,43$ & Go up \\
2018 & 3.774 .304 & 3.356 .460 & $112,45 \%$ & $+20,34$ & Go down \\
\hline
\end{tabular}

In terms of DER, PT Kimia Farma has a DER value of $74.68 \%$ in $2016,92.11 \%$ in 2017 , and $112.45 \%$ in 2018. PT Kimia Farma's debt burden from year to year has increased compared to the amount of equity it has. The smaller the value of this ratio, the smaller the debt owned by the company. Means it can be said that DER in 2016 is in good condition compared to 2017 and 2018 because the greater the ratio value, the greater the debt held so that the ratio gets worse. 
Table 4.6 Calculation Result for 2016-2018 Long Term Debt Ratio

\begin{tabular}{llllll}
\hline Years & long-term debt & total equity & LTDR & delta (+/-) & Information \\
\hline 2016 & 644.946 & 2.271 .407 & $28,39 \%$ & 53,90 & Good \\
2017 & 1.154 .121 & 2.572 .521 & $44,86 \%$ & $+16,47$ & Good \\
2018 & 2.329 .663 & 3.356 .460 & $69,41 \%$ & $+24,55$ & Not Good \\
\hline
\end{tabular}

Source: Processed data

PT Kimia Farma has a value in terms of LTDR, in 2016 amounting to $28.39 \%$, in 2017 amounting to $44.86 \%$, and in 2018 the value of LTDR is $69.41 \%$. This figure shows the amount of long-term debt that is increasing from year to year compared to the equity it has. The largest number owned is in 2018 of 69.41 means that long-term debt in 2018 is increasing compared to the previous year. Berart is getting worse.

\subsection{Activity Ratio Analysis}

Table 7. Results of Calculation of Receivable Turnover for the period of 2016-2018

\begin{tabular}{cccccc}
\hline \multicolumn{3}{r}{ Year } & Credit sales Accounts receivable Accounts receivable turnover Delta (+/-) Information \\
\hline 2016 & 5.811 .503 & 1.696 .209 & $3,43 \mathrm{kali}$ & - & Enought \\
2017 & 6.127 .479 & 2.369 .507 & $2,59 \mathrm{kali}$ & $-1,67$ & Less \\
2018 & 7.454 .115 & 3.774 .304 & $1,97 \mathrm{kali}$ & $-0,75$ & deteriorate \\
\hline
\end{tabular}

The results of receivable turnover (RT) calculations, Based on the table it can be seen that the RT value is 3.43 times in 2016, 2.59 times in 2017 and 1.97 times in 2018. Of course the number has decreased from year to year years so that the higher the ratio, the lower the working capital invested, and vice versa if the ratio is lower means that the greater the accounts receivable with the longer the age of receivables.

Table 8. Inventory Turnover Calculation Results for 2016-2018

\begin{tabular}{|c|c|c|c|}
\hline Year & HPP Sales Stock & inventoryturnover delta $(+/-)$ & Information \\
\hline 2016 & $3.947 .607 \quad 967.330$ & 4,08 & Enough \\
\hline 2017 & $3.925 .599 \quad 1.192 .342$ & $-0,79$ & Go down \\
\hline 2018 & $4.673 .937 \quad 1.805 .736$ & $-1,70$ & descend \\
\hline
\end{tabular}

Based on the table it can be seen that for the value of inventory turnover / Inventory Turn Over / ITO), from 2016 amounted to 4.08 times, 3.29 times in 2017 and 2.59 times in 2018. Of course the number has decreased from year to year year. This ratio measures the efficiency of the use of merchandise inventory in the company so that the performance of management in controlling existing capital in the inventory can be seen as good or unfavorable. A high Inventory Turnover Ratio also shows that a company can effectively sell its purchased inventory, so that excess funds are embedded in inventory.

Table 4.9 Results of Calculation of Working Capital Turnover for the period of 2016-2018

\begin{tabular}{cccccc}
\hline Years & Net Sales & working capital working capital Delta (+/- ) Information \\
turnover & Enough \\
\hline 2016 & 5.811 .503 & 2.271 .407 & $2,56 \mathrm{kali}$ & - & Enough \\
\hline
\end{tabular}




\begin{tabular}{llllll}
\hline Years & Net Sales & working capital working capital Delta (+/- ) & Information \\
turnover & \multicolumn{5}{c}{} \\
\hline 2017 & 6.127 .479 & 2.572 .521 & $2,38 \mathrm{kali}$ & $-0,18$ & Go down \\
2018 & 7.454 .115 & 3.356 .460 & $2,22 \mathrm{kali}$ & $-0,16$ & descend \\
\hline & & & & & Source: Processed data
\end{tabular}

Based on the table it can be seen that the value of working capital turnover (WCT), amounted to $2.56 \%$ in $2016,2.38 \%$ in 2017 and $2.22 \%$ in 2018 . This figure has decreased from year to year year but the value is not too large, so it can be said to get worse. Because a good working capital turnover ratio is one that has increased every year.

Table 10. Results of Calculation of Fixed Assets Turnover for the period of 2016-2018

\begin{tabular}{cccccc}
\hline Years & Sales & fixed assets & fixed asset turnover & Delta (+/-) & Information \\
\hline 2016 & 5.811 .503 & 2.906 .737 & $2,00 \mathrm{kali}$ & - & Not Good \\
2017 & 6.127 .479 & 3.662 .090 & $1,67 \mathrm{kali}$ & $-0,37$ & Go down \\
2018 & 7.454 .115 & 5.369 .547 & $1,39 \mathrm{kali}$ & $-0,28$ & Degenerate \\
\hline
\end{tabular}

Source: Processed data

Based on the table it can be seen that the value of the Fixed Assets Turnover (FAT), was $2.00 \%$ in $2016,1.67 \%$ in 2017 and $1.39 \%$ in 2018 . Of course the number has decreased from 2016-2017, and 2018. Companies that have a high Fixed Asset or Fixed Asset Ratio show that the company is unable to manage its fixed assets efficiently and effectively.

Table 11. Results of Calculation of Total Asset Turnover for the period of 2016-2018

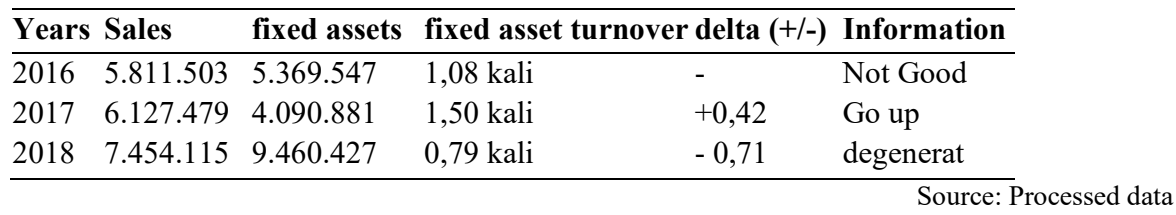

Based on the table it can be seen that the value of the Total Assets Turnover (TAT), was $1.08 \%$ in $2016,1.50 \%$ in 2017 and $0.79 \%$ in 2018 . Of course the number has decreased significantly. quite significant from year to year. So it can be said to get worse, because the higher the turnover, the more efficient the company is using its assets to generate sales.

\subsection{Profitability Analysis}

Table 12. ROI Calculation of PT. Kimia Farma, Tbk in 2016-2018

\begin{tabular}{cccccc}
\hline Years & Net Profit & Total Asset & ROI & delta (+/-) & Information \\
\hline 2016 & 271.598 & 4.612 .562 & $5,89 \%$ & - & Good Enought \\
2017 & 331.708 & 6.096 .149 & $5,44 \%$ & $-0,45$ & Good Enought \\
2018 & 401.793 & 9.460 .427 & $4,25 \%$ & $-1,19$ & Go down \\
\hline
\end{tabular}

Source: Processed data

In terms of ROI ratio, PT Kimia Farmamemiiki ROI ratio of 5.89\% in 2016, 5.44\% in 2017 , and $4.25 \%$ in 2018 . This figure shows a decrease in the value of investment obtained from year to year compared to total assets it has. The higher this ratio means the better the condition of a company. It can be said that in 2016 has a figure of $5.89 \%$ meaning that the 
figure can be said to be large compared to 2017 and 2018. Because in 2017 it slightly decreased by $5.44 \%$ and in 2018 it fell again to $4.25 \%$. It means that the company's condition is getting worse.

Table 13. ROE Calculation of PT. Chemistry Farma, Tbk in 2016-2018

\begin{tabular}{cccccc}
\hline Years & Net Profit private capital & ROE & Delta (+/-) & Information \\
\hline 2016 & 271.598 & 2.271 .407 & $11.96 \%$ & - & Good \\
2017 & 331.708 & 2.572 .521 & $12,89 \%$ & $+0,93$ & Good \\
2018 & 401.793 & 3.356 .460 & $11,97 \%$ & $-0,92$ & Go down \\
\hline \multicolumn{7}{c}{ Source: Processed data }
\end{tabular}

In terms of ROE, PT Kimia Farma Tbk has an ROE ratio of $11.96 \%$ in $2016,12.89 \%$ in 2017, and $11.97 \%$ in 2018. These data show fluctuating movements. ROE shows how successfully the company manages its capital, so that the level of profit is measured by the investment of the owner of the company's capital / stock. It can be said that ROE from 2016 to 2018 experienced a rise that is not much different. 2016 has a figure of $11.96 \%$ and in 2017 it increased by $12.89 \%$, then in 2018 it fell again by $11.97 \%$.

Table 14. Calculation of Gross Profit Margin for the 2016-2018 Period

\begin{tabular}{cccccc}
\hline Years & Gross Profit & Sales & GPM & delta (+/-) & Information \\
\hline 2016 & 1.863 .896 & 5.811 .503 & $32,07 \%$ & - & Good Enought \\
2017 & 2.201 .880 & 6.127 .479 & $35,93 \%$ & $+3,86$ & Go up \\
2018 & 2.780 .178 & 7.454 .115 & $37,30 \%$ & $+1,37$ & Get Better \\
\hline
\end{tabular}

Source: Processed data

PT Kimia Farma Tbk has a GPM ratio of $32.07 \%$ in $2016,35.93 \%$ in 2017 , and $37.30 \%$ in 2018. This figure shows an increase in net profit obtained from year to year because the greater the number the greater acquired porphyte (profiable).

Table 15. Calculation of Net Profit Margin for the 2016-2018 Period

\begin{tabular}{cccccc}
\hline \multicolumn{2}{l}{ Years } & Nett Profit Nett Sales & NPM & \multicolumn{2}{c}{ delta (+/-) Information } \\
\hline 2016 & 271.598 & 5.811 .503 & $4,67 \%$ & - & Enought \\
2017 & 331.708 & 6.127 .479 & $5,41 \%$ & $+0,74$ & Go up \\
2018 & 401.793 & 7.454 .115 & $5,39 \%$ & $-0,03$ & Go down \\
\hline & & & & & \multicolumn{2}{c}{ Source: Processed data }
\end{tabular}

In terms of NPM ratio, PT. Kimia Farma Tbk has a ratio value of 4.67\% in 2016, 5.41\% in 2017 , and $5.39 \%$ in 2018 . The data shows that there is a slow increase from 2016 which has a figure of $4.67 \%$ and there is an increase in in 2017 amounted to $5.41 \%$, but in 2018 the figure decreased to $5.39 \%$. A higher ratio in 2017 is $5.41 \%$. the higher the value of NPM indicates that the company is increasingly efficient operation. The company can reduce unnecessary costs, so the company is able to maximize the net profit obtained.

Table 16. Calculation of Return on Assets for the 2016-2018 Period

\begin{tabular}{cccccc}
\hline Year & Ebit & Total Aktiva & ROA & delta (+/-) & $\begin{array}{c}\text { Information } \\
\text { Enought }\end{array}$ \\
2016 & 383.026 & 4.612 .562 & $8,30 \%$ & - & Go down \\
\hline
\end{tabular}




\begin{tabular}{cccccc}
\hline Year & Ebit & Total Aktiva & ROA & delta (+/-) & Information \\
2018 & 577.726 & 9.460 .427 & $6,11 \%$ & $-1,27$ & degenerat \\
\hline
\end{tabular}

Source: Processed data

In terms of ROA, PT Kimia Farma Tbk ROA ratio of $8.30 \%$ in $2016,7.38 \%$ in 2017 , and $6.11 \%$ in 2018 . The data shows a slow decline from year to year because in 2016 can be said to be more better than 2 years later, namely in 2017 and 2018 it has a presentation of figures of $7.38 \%$ and $6.11 \%$ which means experiencing a decline from 2016 to 2017 and 2018 .

\subsection{Analysis of Financial Performance of PT. Kimia Farma Against Industry Ratio Financial Performance seen from the Liquidity Ratio}

Table 17. Liquidity Ratio Calculation

\begin{tabular}{ccccc}
\hline Keterangan & \multicolumn{3}{c}{ Kimia Farma } & Ratio Industri \\
& $\mathbf{2 0 1 6}$ & $\mathbf{2 0 1 7}$ & $\mathbf{2 0 1 8}$ & \\
\hline Likuiditas & $\mathbf{( \% )}$ & $(\%)$ & $(\%)$ & $(\%)$ \\
Current Ratio & 1,24 & 1,04 & 0,88 & 1,91 \\
Quick Ratio & 0,83 & 0,70 & 0,58 & 1,41 \\
Cash Ratio & 0,28 & 0,28 & 0,32 & 0,57 \\
\hline
\end{tabular}

Source: research results

PT. Kimia Farma has Current Ratio from 2016 to 2018 in a row of 1.24, 1.04 and 0.88 . This figure shows a slow decline from 2016 to 2018. This shows that the growth of current assets with current debt is greater than the growth of current debt. Compared to the industry ratio for the same period of 2016 to 2018, PT. Kimia Farma Tbk has a current ratio far below the industry average ratio in 2016-2018 of 1.91, so it can be concluded that the current ratio of PT Kimia Farma is worse than the industry average ratio and financial performance is also worse. in 2016- 2018.

In terms of Quick Ratio between 2016-2018, PT Kimia Farma has a QR value of 0.83 , $0.70,0.58$. This shows a definite decrease from year to year. When compared with the industry QR for the period of 2016-2018 which is 1.06, the Pharma chemical QR is below the industry ratio. This situation shows that Farma's chemical financial performance is not good. PT. Kimia Farma has total current assets after being reduced by less inventory than the amount of short-term liabilities to be paid.

The value of PT Kimia Farma's cash ratio from 2016-2018 is $0.28,0.28$, and 0.32 . The number is still below the industry ratio which reaches 0.43 . Based on this comparison, it can be said that PT Kimia Farma has a cash ratio that is less good compared to the industry ratio.

\subsection{Solvency Ratio Analysis}

Table 18. Solvency Ratio

\begin{tabular}{|c|c|c|c|c|}
\hline \multirow[t]{2}{*}{ Keterangan } & \multicolumn{3}{|c|}{ Kimia Farma } & \multirow[t]{2}{*}{ Ratio Industri } \\
\hline & 2016 & 2017 & 2018 & \\
\hline Solvabilitas & $(\%)$ & $(\%)$ & $(\%)$ & $(\%)$ \\
\hline Total Asset Rasio (Dar) & 70,29 & 57,92 & 39,9 & 28.73 \\
\hline Equity Rasio (Der) & 74,68 & 92,11 & 112,45 & 46.57 \\
\hline Long Tem Der (Ltdter) & 28,39 & 44,86 & 69,41 & 71.90 \\
\hline
\end{tabular}


PT Kimia Farma has a DAR value in $2016-2018$ of $70.29 \%, 57.92 \%$ and $39.90 \%$. From year to year there is a decrease, meaning that the burden of pharma chemical debt decreases compared to the total assets owned. The movement is an indication of the improving financial situation of PT. Kimia Farma. However, if compared to the industry ratio for DAR of $21.55 \%$, the chemical pharmaceutical debt burden is still far above the industry average. So it can be said that the financial performance of pharma chemicals is in a bad condition.

In terms of DER, PT Kimia Farma has a DER value of $74.68 \%, 92.11 \%$ and $112.45 \%$. PT Kimia Farma's debt burden from year to year has increased compared to the amount of equity it has. When compared with the industry ratio of $40.92 \%$ in the same period, it can be said that DER of PT Kimia Farma is in a bad condition. In terms of LTDR in 2016-2018 PT Kimia Farma LTDR value of $28.39 \%, 44.86 \%$ and $69.41 \%$. This figure shows the amount of longterm debt that is increasing from year to year. When compared with industry ratios in the same period of $53.90 \%$, the financial condition of PT Kimia Farma is still in poor condition because the amount of long- term debt is smaller than the average long-term debt of similar companies, so it can be said PTR LTDR Farma is in poor condition.

\subsection{Activity Ratio Analysis}

Table 19. Activity Ratio

\begin{tabular}{|c|c|c|c|c|}
\hline \multirow[t]{2}{*}{ Keterangan } & \multicolumn{3}{|c|}{ Kimia Farma } & \multirow[t]{2}{*}{ Ratio Industri } \\
\hline & 2016 & 2017 & 2018 & \\
\hline Aktivitas & (Kali) & (kali) & (kali) & (kali) \\
\hline Receivable Turnover & 3,43 & 2,59 & 1,97 & 18.32 \\
\hline Inventory Turnover & 4,08 & 3,29 & 2,59 & 3.40 \\
\hline Working Capital Turnover & 2,56 & 2,38 & 2,22 & 1,20 \\
\hline Fixed Assets Turnover & 2 & 1,67 & 1,39 & 1,64 \\
\hline Total Assets Turnover & 1,08 & 1,5 & 0,79 & 1,05 \\
\hline
\end{tabular}

PT Kimia Farma Tbk has a RT ratio in 2016 of 3.43 times, in 2017 of 2.59 times and 2018 of 1.97. There was a significant decrease from year to year. When compared with the industrial RT ratio of $13.74 \%$, the financial performance of PT. Kimia Farma Tbk can be said to be good because it is far above the industry average. In terms of ITO ratio, PT Kimia Pharma has a ratio value of 4.08 times in 2016, 3.29 times in 2017, and 2.59 times in 2018 . The figure shows a decrease from year to year. When compared with the industry's ITO ratio of $2.55 \%$, the pharmaceutical chemical financial performance is said to be good because it is above the industry ratio. In terms of WCT, PT. Kimia Farma Tbk has a WCT ratio of 2.56 times in 2016, 2.38 times in 2017, and 2.22 times in 2018. This figure shows that performance has been declining gradually from year to year. When compared to the industry's WCT ratio of $1.50 \%$, the condition of PT Kimia Farma Tbk's financial performance is still above the industry's ratio so it can be said to have good financial performance.

In terms of FAT, PT. Kimia Farma Tbk has a value ratio of 2.00 in 2016, 1.67 in 2017, and 1.39 in 2018 . When compared with the industry FAT ratio of $1.23 \%$, then PT Kimia Farma has a good financial performance because it is located above the industry ratio. In terms of TAT ratio, PT Kimia Pharma has a ratio value of $1.08 \%$ in $2016,1.50 \%$ in 2017 , and $0.79 \%$ in 2018. This figure shows an increase in TAT ratio from year to year. When compared with the industry TAT ratio of $0.78 \%$, PT Kimi Farma has a good financial performance because it is 
above the industry ratio.

\subsection{Analysis of Profitability Ratios}

Table 20. Profitability Ratio

\begin{tabular}{|c|c|c|c|c|}
\hline \multirow[t]{2}{*}{ Keterangan } & \multicolumn{3}{|c|}{ Kimia Farma } & \multirow[t]{2}{*}{ Ratio Industri } \\
\hline & 2016 & 2017 & 2018 & \\
\hline Proftabilitas & $(\%)$ & $(\%)$ & $(\%)$ & $(\%)$ \\
\hline Gross Profit Margin & 32,07 & 35,93 & 37,3 & 39,68 \\
\hline Net Profit Margin & 4,67 & 5,41 & 5,39 & 7,74 \\
\hline Return On Invesment & 5,89 & 5,44 & 4,25 & 7.03 \\
\hline Return On Asset & 8,3 & 7,38 & 6,11 & 10,00 \\
\hline Return On Equity & 11,96 & 12,89 & 11,97 & 11,08 \\
\hline
\end{tabular}

PT Kimia Farma Tbk has a GPM ratio of $32.07 \%$ in $2016,35.93 \%$ in 2017 , and $37.30 \%$ in 2018. This figure shows an increase in net profit gained from year to year compared to the total assets it has. When compared with the industrial GPM ratio of $39.68 \%$, the GPM ratio of PT Kimia Farma is below the industry ratio. So it can be said that the financial performance conditions of PT. Kimia Farma Tbk is still below the industry average. In terms of NPM ratio, PT. Kimia Farma Tbk has a ratio value of $4.67 \%$ in $2016,5.41 \%$ in 2017 , and $5.39 \%$ in 2018 . The data shows a slow increase from year to year. When compared to the industry's NPM ratio of $7.74 \%$, the financial performance of PT Kimia Farma Tbk is still below the industry average for three consecutive years.

In terms of ROA, PT Kimia Farma Tbk ROA ratio of $8.30 \%$ in $2016,7.38 \%$ in 2017 , and $6.11 \%$ in 2018 . The data shows a slow decline from year to year. When compared with the industry ROA ratio of $10.00 \%$, the ROA ratio of PT Kimia Farma in 2016 is above the industry ratio. So it can be said to be good, whereas in 2017 until 2018 the value of the financial ratios is below the industry ratio, the condition of the financial performance of PT. Kimia Farma Tbk is still below the industry average for three years in a row. In terms of ROE, PT Kimia Farma Tbk has an ROE ratio of $11.96 \%$ in $2016,12.89 \%$ in 2017 , and $11.97 \%$ in 2018. These data show fluctuating movements. When compared with the industry ROE ratio of $11.08 \%$, the financial performance of PT Kimia Farma is above the industry average. ROE is the only ratio of PT. Kimia Farma, which is above the industry average for three years in a row.

In terms of ROI ratio, PT Kimia Farma has an ROI ratio of 5.89\% in 2016, 5.44\% in 2017, and $4.25 \%$ in 2018 . This figure shows a decrease in the value of investment obtained from year to year compared to total assets it has. When compared with the industry ROI ratio of $7.03 \%$, the ROI of PT Kimia Farma for 2016-2017 is below the industry average ratio.

\section{Conclusions}

a) The results of the measurement of liquidity ratios at PT Kimia Farma Tbk from 2016 to 2018 have a ratio that tends to decrease (increasingly illiquid / worsening), the calculation of the solvency ratio of PT Kimia Farma of all indicators of the solvency ratio tends to increase (increasingly non-solvable). The results of calculations using PT Kimia pharma activity ratios of all activity ratios show the tendency of the smaller the 
rotation (the more inefficient). While the calculation of the Profitability Ratio as a whole has a stable ratio value still still gets the highest profit is ROE of $11.08 \%$ in 2018. Thus it can be concluded that the financial performance of PT. Kimia Farma tends to decrease, as seen from the decrease in the liquidity ratio, the activity ratio and the increase in the solvency ratio, although the profitability ratio is still stable positive. If the ratio beyond profitability can be controlled, the profitability ratio will increase.

b) Financial performance of PT. Kimia Farma based on liquidity ratios, solvency ratios, activity ratios and profitability ratios when compared to industry ratios shows that liquidity ratios are smaller / below the industry average ratio, solvency ratios above the industry average ratio, activity ratios below average ratios average industry and profitability ratios are also below the average industry ratios which all show worse performance than the performance of similar companies, so it can be concluded that the financial performance of PT. Kimia Farma tends to decline and is worse than the performance of similar companies.

As an input the author suggests several suggestions that would be useful and useful for PT. Kimia Farma, Tbk are as follows:

a) From the results of the analysis of liquidity ratios the company must strive to increase liquidity at a minimum equal to the industry average which will automatically reduce the additional burden because it is in an illiquid (illiid) position.

b) Solvency Ratio of PT. Kimia Farma Tbk is higher than the industry ratio which means that there is a higher interest expense, so it must be pursued by optimizing the reduction in the age of receivables.

c) From the aspect of activities far below the average evidence that asset management is very inadequate with asset recovery that is only 1.02 times. How to increase asset turnover, supplies, working capital which indicates an increase in the efficiency of company management.

d) Profitability will automatically increase optimally if the problem at a ratio below similar companies such as liquidity, solvency and actuality ratios can be overcome at least the same as the industry average ratio. Because of that ratio the emergence of unnecessary expenses and ultimately will reduce profitability.

\section{References}

[1] Darsono, Ashari. (2009). Aplikasi analisis laporan keuangan.Yogyakarta: Penerbit Liberty Yogyakarta. Fahmi, Irham. (2015). Analisis laporan keuangan. Bandung: Penerbit Alfabeta

[2] Hanafi, Mahduh dan Abdul Halim. (2012). Analisis laporan keuangan. Yogyakarta: (UPP) STIM YKPN. Handoko, T. H. (2009). Manajemen, Yogyakarta: BPFE Yogyakarta.

[3] Harahap, S.Safry.(2008). Analisis kritis atas laporan keuangan. Jakarta: Rajawali Persada.

[4] Harmono. (2009). Manajemen keuangan berbasis balanced scorecard (Pendekatan teori, kasus, dan riset bisnis). Jakarta: Bumi Aksara

[5] Hery.(2015). Analisis laporan keuangan. Edisi kesatu. Yogyakarta: Center For Academic Publishing Services. Horne, James C. Van dan John M Wachowicz, Jr. (2012). Prinsip-prinsip manajemen keuangan. Edisi ketiga belas. Jakarta: Salemba Empat.

[6] Kamaludin. (2011). Manajemen keuangan, konsep dasar dan penerapannya. Bandung: Mandar Maju. Kasmir. (2008). Bank dan lembaga keuangan lainnya. Edisi Revisi 2008. Jakarta: PT. Rajagrafindo Persada. Kasmir. (2010). Pengantar manajemen keuangan. Jakarta: Kencana Prenada Media Group. 
[7] Kasmir. (2014). Analisis laporan keuangan. Edisi satu. Cetakan Ketujuh, Jakarta : PT. Raja Grafindo Persada. Kasmir. (2016). Analisis laporan keuangan. Jakarta: PT. Raja Grafindo Persada,

[8] Hasibuan, S.P.M. (2012). Manajemen sumber daya manusia. Jakarta: PT Bumi Aksara. Mulyadi. 2007. Sistem Perencanaan dan Pengendalian Manajemen. Jakarta: Salemba Empat Munawir, S. (2012). Analisis informasi keuangan. Yogyakarta: Liberty,

[9] Oktrima, B. (2018). ANALISIS KINERJA KEUANGAN MENGGUNAKAN RASIO PROFITASBILITAS DAN LIKUIDITAS PADA PT. RAMAYANA LESTARI SENTOSA, TBK. Jurnal Ekonomi Efektif, 1(1).

[10] Sartono, A.(2012). Manajemen keuangan teori dan aplikasi. Edisi 4. Yogyakarta: BPFE UGM Yogyakarta.. Purnomo, S., \& Pasaribu, V. L. D. (2019). Pergerakan Harga Saham Pt Adaro Energy Tbk (Adro) Pada Pengumuman Dividen Interim Tahun Buku 2018. Jurnal Ekonomi Efektif, 2(1).

[11] Sugiyono.(2001). Metode penelitian, Bandung: CV Alfa Beta.

[12] Sugiyono.(2008). Metode penelitian kunatitatif kualitatif dan R\&D. Bandung: Alfabeta

[13] Sujarweni, V. Wiratna. (2017). Analisis laporan keuangan. Penerbit Pustaka Baru Press Perpustakaan Nasional RI: Katalog Dalam Terbitan (KDT). Yogyakarta

[14] Sutrisno. (2012). Manajemen keuangan teori, konsep dan aplikasi. Edisi Pertama. Cetakan ketujuh. Penerbit: Ekonesia, Yogyakarta.

[15] Wartono, T. (2018). Pengaruh Current Ratio (CR) dan Debt to Asset Ratio (DAR) terhadap Return On Asset (ROA) pada PT. Astra International, Tbk.

[16] Tumanggor, M., \& Saputra, A. (2020, January). ANALISIS RASIO LIKUIDITAS DAN PROFITABILITAS UNTUK MENILAI KINERJA KEUANGAN PADA PT. SIERAD PRODUCE TBK. In PROCEEDINGS (Vol. 1, No. 1).

[17] http://www.idx.co.id/perusahaan-tercatat/laporan-keuangan-dan-tahunan/ 